\title{
Current Phenomenon Tension Between the United States and Iran in the Middle East
}

\section{Musyfiqur Rahman}

Postgraduate Interdisciplinary Islamic Studies Concentration in Middle East

Studies, State Islamic University of Sunan Kalijaga, Yogyakarta

Email:budakmu.allah@gmail.com

\begin{abstract}
The tensions between the United States and Iran, as can be seen lately, have reached a rare point in the many escalations in recent years in the Middle East. Apart from the historical factors that began since Iran succeeded in carrying out a revolution by subverting the regime of Shah Mohamed Reza Pahlavi, another factor further heightening the geopolitical dynamics of the region was the departure of the US under President Donald Trump from nuclear agreement of the Joint Comprehensive Plan of Action (JCPOA), followed by the enactment of tighter economic sanctions on Iran. in this article, the writer tried to explain the phenomenon of tensions between the two countries using the national interest theory according to Scott Burchill, by reading the strategic goals of the political attitudes of the US in the Middle East for its national interest. the findings of this article confirm that the US does not want a large force in the region disturbing its national interest. However, the US also does not want to launch an open war against Iran but rather tighten a series of sanctions economically.
\end{abstract}

Keywords: Tension, United States, Iran, National Interest, Middle East, $J C P O A$

\begin{abstract}
Abstrak
Ketegangan antara Amerika Serikat dan Iran, seperti dapat dilihat belakangan ini, telah mencapai titik langka dalam banyak peningkatan dalam beberapa tahun terakhir di Timur Tengah. Terlepas dari faktor-faktor historis yang dimulai sejak Iran berhasil melakukan revolusi dengan menumbangkan rezim Shah Mohamed Reza Pahlavi, faktor lain yang lebih meningkatkan
\end{abstract}


dinamika geopolitik di kawasan itu adalah kepergian AS di bawah Presiden Donald Trump dari perjanjian nuklir negara tersebut. Rencana Aksi Bersama Komprehensif(JCPOA), diikuti dengan diberlakukannya sanksi ekonomi yang lebih ketat terhadap Iran. Dalam artikel ini, penulis mencoba menjelaskan fenomena ketegangan antara kedua negara menggunakan teori kepentingan nasional menurut Scott Burchill, dengan membaca tujuan strategis dari sikap politik AS di Timur Tengah untuk kepentingan nasionalnya. Temuan artikel ini mengkonfirmasi bahwa AS tidak ingin kekuatan besar di kawasan itu mengganggu kepentingan nasionalnya. Namun, AS juga tidak ingin melancarkan perang terbuka terhadap Iran tetapi lebih memperketat serangkaian sanksi ekonomi.

Kata kunci: Ketegangan, Amerika Serikat, Iran, Kepentingan Nasional, Timur Tengah, JCPOA

\section{INTRODUCTION}

In the beginning, it was hegemony. It is a desire to rule by suppressing weak social structures. Gramsci defines hegemony as the embodiment of a class and all its components carrying out the power project to grip the lower classes through violence and persuasion (Simon 2004, 16). It is illustrated in the recent phenomenon, the tensions between the United States and the Islamic Republic of Iran. America, as a superpower, moves all its components and instruments to control Iran's "class" state as a structure under the United States.

The desire of the United States to launch a more massive hegemony to Iran began when Donald Trump brought the United States out of Iran's nuclear agreement or the Joint Comprehensive Plan of Action (JCPOA). Even since the beginning of his campaign, Trump has been touting for bringing America out of the agreement, which Trump called the "worst agreement" ever made by the United States. Indeed, this criticism leads to the $44^{\text {th }}$ United States President, Barack Obama, because the agreement was made and agreed during Obama's leadership.

Iran, as the first Islamic country in the world succeeding in igniting its revolutionary fire and was very popular in 1979 (Esposito 1997, 77), up to now has values and 
significance for political maps and policymakers in the Middle East. One of its strategic values is because politically Iran has control over the Persian Gulf and the Strait of Hormuz, which is a shipping lane for oil carriers from the region to Western countries, besides Iran itself is one of the largest oilproducing countries in the region (Burdah 2008, 66-67).

In addition to the strategic geopolitical value making these two countries to face each other diametrically, there is another fundamental factor that is quite primordial, namely excessive fear of monolithic Islam, which for John L. Esposito is an unfounded Western myth, but it continues to be produced for the sake of achieving certain interests. Without being based on authentic historical reality about Islam, Western commentators on Islam have distorted much of the reality of Islam itself (Esposito 1996, 202). They are actually building a myth to legitimize hegemonic purposes. Including in the case of Iran, America made the main spectrum in building meta narration about the latent dangers of the influence of the Islamic Revolution to achieve its national interest.

Since Ayatollah Khomeini appeared as one of the symbols for the resistance movement over Western hegemony, it was increasingly emphasized above the view that Islamic fundamentalism or militant Islam is a real threat to the West. How Khomeini discussed frontal narratives by calling the United States "Great Satan" or “Destroy America!” as a jihad against foreign infidels who have usurped the rights of Muslims as an oppressed party (Esposito 1996, 13).

In recent times, several important events have occurred, which have either directly or indirectly added to the escalation between the United States and Iran. From shooting down the most sophisticated unmanned aircraft ever made by the United States to take a hostage of British warships, then bombing two Saudi Arabian Aramco oil refineries, and also endless wars in Yemen.

The study of tensions between the United States and Iran is widely discussed by researchers, such as the article written by Enayatollah Yazdani in the journal Sociology Study entitled Confrontation between America and the Islamic Republic of Iran. in his article, Yazdani revealed that the United States and Iranian tensions in the last few decades were rooted in three fundamental issues: 1). the nuclear program problem, 2). 
Development of ballistic missiles, and 3). Iran's influence in the region (Yazdani 2019, 180). Yazdani considered these three issues as a serious threat to the United States' interest in the region. Thus, the escalation is increasing and heating up from time to time. However, Yazdani also concluded that the confrontation strategy done by the United States against Iran led to the option "No War and No Peace".

The second article was written by Albert B. Wolf in the Comparative Strategy journal entitled After JCPOA: American Grand Strategy toward Iran. If Yazdani, in his article, identified three fundamental problems related to Iran's policy, which the United States considered would interfere with its national interest, then Wolf revealed four fundamental United States' interests in the Middle East that directly related to Iran's behavior: 1). Energy security, 2). the proliferation of the nuclear program, 3). the problem of terrorism, and 4). Israeli security guarantee (Wolf, 2018, 22).

However, the two articles have not offended the issues of regional crisis in which Iran is considered by the United States to have a very significant role, especially in supplying weapons and military funds for resistance movements spread in several countries in the Middle East, such as the Yemeni Houthis and others. Therefore, the writer would review some of the current tension phenomena regarding Iran's involvement in the constellation in the Middle East and how it makes Iran confront the United States' national interest.

\section{RESEARCH METHOD}

In the preparation of this study, the writer relied on primary sources of library material that pretty much explains the historical and theoretical framework around the themes raised in this study. the effort to portray an area during an escalating situation between two countries, which both want to show the existence, domination, and fulfillment of their national interest in the region, certainly requires a comprehensive and analytical study. the writer also enriched the data by following the latest news related to the tensions between the United States and Iran in the region and specifically news about this research, both from printed newspapers or online media.

\section{THEORY}

In this study, the writer made the national interest theory a surgical tool for analyzing the construction 
of phenomena regarding the United States and Iranian tensions in the region. According to Scott Burchill, the true national interest refers to the interest of a country by relying on the power it has (Scott 2005, 35). Furthermore, Burchill describes his analysis of national interest in four perspectives; realism, Marxism, liberalism, and English Schools, each of which has a four-way approach and certainly has its implications and implications in formulating and deciphering a phenomenon of international relations. However, the writer focused only on using the perspective of realism. Realism is a perspective trying to develop a full conceptualization related to the national interest. This view builds the assumption that national interest must be seen from the framework of the interests of a country as a high institution in politics representing society's interest as well as the character of anarchism in the arena of international politics (Scott 2005, 31-32). in this study, the writer would explain how this realism perspective has taken place in the map of the United States political policy since the beginning of the post-revolution tensions od the United States-Iran until now, under the pretext of realizing its national interest and making efforts to quell
Iran's influence in the region. Hence, the main focus of this article is to look at the United States' national interest in the constellation with Iran and, at the same time, see how Iran survives resistance.

\section{The Beginning of Iran-United States Tensions}

Islam reappeared as one of the global forces taken into account on the international political stage in the 1970-1980s. Space for the spirit of the rise of Islam covers various parts of the world. Islamic government leaders and opposition groups also use religion to legitimize the support of the people (Esposito 1996, 21). Moreover, the only success of this Islamic revival to the scale of the country was the Iranian Islamic Revolution.

Iran and America relations deteriorated rapidly after the Islamic Revolution in 1979. the new Iranian regime under the control of mullahs no longer trusted America because it supported the Shah of the past, Mohamed Reza Pahlavi. When the American government accepted the overthrow Shah to enter America for treatment due to cancer, a group of Iranian students stormed the American Embassy in Tehran and held 52 American diplomats on 
November 4, 1979 (Rogan 2017, 590).

Recorded on January 20, 1981, 52 American diplomat hostages detained at the United States Embassy for 444 days finally left Iran. A few days later, they arrived in America, and the country and the mass media cheered on their return by congratulating them on the "return of the hostages". For days this event received special attention from various media in the world, complemented by various analyzes related to the diplomatic process taking place behind the scenes between the two parties until an agreement was reached for the release of the hostages. Besides, the sentiments emerging in the mass media narrative were the heroism of the United States and Iranian barbarism. on January 31, 1981, the New Republic revealed the "ransom" issued by the Jimmy Carter administration to meet Iran's demands to free the hostages (Said 1986, 7-8).

The West, primarily America, has witnessed a series of "Islamic revival" events with certain doubts mixed with fear. However, the image of the Iranian revolution was present to fulfill the complexity of the Western outlook on Islam. Since 1979, terms associated with
Islam, such as fanaticism, Islamism, fundamentalism, and Islamic militancy, have often appeared in the mass media without a clear understanding of its meaning and substance (Esposito, Arkoun, and Al-Jabiri 2002, 182).

On the surface, the IranUnited States crisis represented an ideological and cultural war between the governments of two different political systems. Nevertheless, at a deeper level, Iran's portrayal of Satan increasingly shows the severity of the views of United States officials and their fear of regimes controlled by the mullahs by using Islam as legitimacy to attack the interests of America and its allies. Since 1979, Iran has staked the legitimacy of power in the region by using its Islamic (Shia) identity (Gerges 2002, 50-51).

Ayatollah Khomeini and his revolution by the Western media are described as having a reactionary character carrying a "medieval" feel imaged as a century of backwardness and static. Furthermore, Islam is attached to negative abstractions alleged by Western scholars as inhibiting the development process and hindering modernization theories (Eickelman and Piscatori 1998, 34). Even for Europe, Islam is an eternal trauma, symbolized 
as terror, destruction, and hordes of barbarians who are loyal and despised (Said 2016, 88). Moreover, it is hard to rebuild good relations between the United States and Iran. Especially after the September 11, 2001 incident, instead, the United States put Iran on the terrorist blacklist (Tamara 2017, 378).

\section{Crucial Point of Current Tension}

In addition to the tensions occurring since the beginning of Iran's revolution, the current tension was caused by several issues. One of the main triggers is since the United States, under the rule of Donald Trump, left the nuclear agreement or the Joint Comprehensive Plan of Action (JCPOA) unilaterally. Trump considered this agreement as "the worst agreement that should not have been possible". Thus, for this reason, Trump has again imposed harsh sanctions on Iran (Mikail $2018,70)$.

The sanctions regime imposed by the United States on Iran began in 1979 in the form of economic and political sanctions. However, in this situation, Iran is still able to show its superiority as these mullah countries do not necessarily go bankrupt due to the United States' sanctions. It is exactly from this point that Iran learned to continue to improve and become an independent country, meaning that it does not depend on the global economic cycle controlled by the United States and the international Zionist network. Based on data published in the influential economic weekly media, Business Week shows that Iran, with a population of 69 million, has a reserve of 35 billion USD, income per capita that reaches 6,800 USD, and income growth of $5.9 \%$. Indeed, the United States' economic and political sanctions in no way affect Iran's socio-economic pressures. One impact of the United States' economic sanctions is the emergence of a phenomenon in which Iran seems "thirsty for goods, foreign capital and technology". Until 2004, foreign investment was minimal, and it was estimated to only around 2 billion USD per year (Sihbudi 2007, 269).

The economic situation under pressure from America's sanctions increasingly complicated the tactical steps of the Iranian government in the decision-making process to keep domestic stability safe and under control. on November 1618,2019 , the Iranian government faced demonstrations taking place in various cities. the main trigger was the government's decision to revoke part of the fuel subsidy so 
that fuel prices increased by up to 50\% (Kompas, n.d.).

Iranian President Hassan Rouhani said that Iran was facing a difficult situation because it needed huge funds to meet the benefits and services of 60 million underprivileged people. This source of income is usually from oil exports. Due to America's sanctions making it very difficult for Iran to conduct global-level transactions with its partner countries for oil exports, the government was forced to raise domestic fuel prices (Kompas, n.d.). If Iran does not take this step, the government will face a far greater crisis as the government has not maintained economic stability.

By tightening sanctions on Iran, the American attitude increasingly made it difficult for the countries involved in this agreement, namely the five permanent members of the UN Security Council (US, UK, France, Russia, China) and the European Union represented by Germany. However, they experience a dilemma between maintaining an agreement with Iran as a country having strategic values in the region and also supporting the sanctions regime imposed by America.

Although Trump's controversial move has angered many parties, he remained firm in his stance. Even many people opposed his policy. As for Trump's goal of bringing the United States out of the nuclear agreement, then tightening a series of sanctions on Iran, according to Munir Shaqiq, Secretary-General of the Palestinian People's Congress Abroad, is because of four factors. First is to review Iran's nuclear agreement by considering tighter restrictions on Iran for nuclear development projects, even on the pretext of security. Second is the ban on Iran to develop ballistic missiles. Third, Iran must withdraw from intervention and provide missile supplies to Syria. Fourth, Iran must stop supplying weapons to Hezbollah in Lebanon and Hamas in Gaza (Shaqiq 2019, 119).

There is another aspect Munir Shaqiq does not attend to, namely the problem of Iran's involvement in the Yemen conflict by supplying sophisticated weapons to the Houthi militia as Houthi does not deny the involvement of Iran in providing political support, military, and flush funds (Al-Daghsyi 2013, 85). However, the United States wants Iran to stop and immediately withdraw from its intervention in the Yemen conflict. the United States wants the Yemen conflict to end immediately with Saudi Arabia and its coalition winners. Then, 
these points become the main trigger Trump withdrew from the agreement to return the nuclear talks to zero so that these points could be included in negotiations. Definitely, Iran rejected negotiation efforts beyond the nuclear issue, while the United States insisted on making the external aspects part of the negotiating material.

The dual political tendencies played by America in the region, on the one hand, it wants the stability of the region free from the threat of nuclear weapons, but on the other hand, it allows Israel to carry out nuclear development as free as possible without any supervision. This action exactly prevents the balance of strategic geopolitical interests among policymakers in the region. Indeed geographically, Israel's position is very vulnerable because this small country is surrounded by states and resistance movements, and without natural geographical boundaries either in the form of large mountains or wide waters providing sufficient defensive positions in depressed conditions (Burdah 2014, 144). This situation has undoubtedly silenced America and even supported Israel's nuclear program.

Even since the beginning of the process of initiating the
Israeli nuclear project, known as the Shimon Peres Negev Nuclear Research Center, or sometimes also called the Dimona reactor, the CIA has known it. Even the CIA itself submitted an essential document to the US Secretary of State, John Foster Dulles, in 1963, informing in detail that Israeli Prime Minister David Ben Gurion had released a document related to the nuclear reactor construction project in 1956. in secret, the US intelligence assisted Israel in ensuring that the Israeli nuclear reactor construction project is realized. Under the pretext of the 1967 War, which almost threatened Israel's existence due to the onslaught of Arab coalition forces (Salim 2001, 291-92), the United States fully provided support and assistance for Israel's nuclear program as a major bulwark for military threats and distress which could come at any time.

To answer the anomalies of the political attitudes of the United States, which always play double politics to realize its national interest, Iran is not motionless. Evidently, since RQ-A4 Global Hawk, the drone US military scouts dropped by the Islamic Revolution Guards Corps (IRGC) in the southern Persian Gulf, precisely at 19:44 GMT on Wednesday, June 19, 
2019, or 00:14 Thursday local time (Jakarta Greater 2019), tensions in the region between the United States and Iran has reached the rare point of the many escalations in recent years. After the shooting, the United States, at Trump's instructions, had declared an open war with Iran, but shortly after the decision was made; Trump withdrew his statement because he received information from one of his generals that an attack on Iran's three main points would sacrifice 150 lives (Detik.com 2019).

Much speculation has been circulating among analysts regarding changes in Trump's attitude at the last minute as part of the upheaval between his military advisers who wanted war with Trump's commitment not to decide to open warfare immediately. It could be because Trump does not want to take risks difficult to reckon with since an open war with Iran will cause widespread tensions throughout the region where proxies will engage in this war and will automatically become a threat to Israel's security so vulnerable.

Besides, Trump is considering calculations for investment in the upcoming 2020 elections. If the war with Iran is fought in the last years of his leadership period, his votes will be seriously threatened when the war occurring cannot be resolved immediately. Therefore, he chose to ignore the input of his advisers who tended toward open war.

\section{Post-Aramco Saudi Bombing}

Indeed the complexity of the various tensions in the Middle East has a parallel chain connecting one problem point to another. When discussing the problem of the Yemen conflict, it certainly cannot stand alone without involving the parties involved in the conflict. Including when discussing the increasing escalation between the United States and Iran, it also can not be separated from various proxy wars throughout the region. These factors cause the complexity of the breaking of the embers in the Middle East.

As a country leading the fight against the Houthi insurgency in Yemen, Saudi Arabia must accept the harsh reality after years of bombarding Yemen. It is because the Houthi militia began to attack by targeting Saudi Arabia's vital objects, namely two of Aramco's biggest oil refineries in the Abqaiq and Khurais regions. This attack used several unmanned aircraft (drones) able to penetrate Saudi Arabia's air defense bases (Kompas, n.d.). 
Meanwhile, Saudi Arabia's military defense base, especially its air defense, is increasingly being highlighted by the public. It is because Saudi Arabia is serious about maintaining its sovereignty, especially in the midst of vulnerable situations and conditions as it is today. Billions of USD have been spent on buying weapons and sophisticated defense systems from Europe and the United States. the weapons purchased from the United States include Avengers short-range missiles, I-Hawk midrange missiles, and Swiss shortrange missiles named Orelinkons (Kompas, n.d.). Moreover, the USmade Patriot missile defense system was also installed in various major cities and several other strategic facilities.

As if dissatisfied with the Houthis claiming responsibility for the incident, Saudi Arabia and the United States agreed to throw accusations at Iran, or at least, Iran was behind the attack on Saudi Arabia's oil refineries. However, Iran's Foreign Minister, Mohammad Javad Zarif, denied Iran's involvement in the Aramco refinery shooting and further stressed that if this tension requires military involvement, Iran firmly states that it will fight seriously (Schemm and Loveluck 2019).

\section{Calculation of US Open War with Iran}

Looking at various phenomena today, it is true what was expressed by Martin Wight that what distinguishes modern history from the history of the Middle Ages is the superiority of the idea of power over the idea of truth (Sahide 2017, 86). Determination of winners and losers is no longer measured according to a set of values and other social institutions, but by testing the extent to which power and hegemony can create a structured and systematic movement to control a country for its national interest. Therefore, the United States, as a superpower, exists without value or wants to surpass all values. Being above all existing order values, the United States, in its hegemonic projects, hid many reasons behind the pretext of human rights and democracy. However, these drives are never consistent. If it is truly consistent, inevitably, it will clash with its national interest.

It is true what Samuel P. Huntington said when addressing the issue of clashes between civilizations reflected by a particular interest and purpose by relying 
on the legitimacy of identities intentionally made face to face:

People use politics not only for their interests but also to state their identity. We will only know who we are when we know who "we are not" and that can only be known through "with whom we are dealing with" (Huntington 2012, 8).

It is also seen in various nerve wars between American and Iranian officials, where both parties constructed each other as superior to others, either by relying on a particular identity to give legitimacy or even to bring down.

In the arena of international politics, a country will be thrown from a competitive global arena when it fails to realize its national interest properly. For Morgenthau, international politics is the same as politics in general, the arena of power struggles. Whatever is the ultimate goal of political power, power is always the most immediate goal (Morgenthau 2010, 33). in the context of its dispute with Iran, America wants to realize its national interest by grounding in the direction of policies formulated and then implemented through its foreign policy.

US foreign policy is often discussed in terms of the dialectical tension between two opposing poles: legalism-moralism and pragmatism-realism. Alternatively, in other words, American foreign policy goes back and forth between real politics and moralism. For supporters and practitioners, realism is a clear, orderly, straightforward, and firm understanding of policy formulation based on well-defined state interests. the essence of this realism is the national interest closely related to national security (Hastedt 2000, 28-34).

One of the most critical aspects of power capable of influencing a variety of hegemony projects is military power. According to Kabi Al-Khuri, from the Center for Arab Unity Studies, citing data from Global Firepower assesses that Iran, as one of the countries in the region, is indeed ranked $14^{\text {th }}$ in the world's strongest military. Many researchers doubt the true strength of Iran because these calculations exclude nuclear power (Al-Khuri $2019,165-66)$. If it is included, Iran's military might be above that rank. on this side alone, America is sure to calculate very well when it has to deal directly with an open war with Iran.

It is also important to see Trump's attitude, which, from the very beginning, was known to be aggressive in leading Uncle Sam's 
country. Seeing from his sarcastic attitude, undoubtedly, many people assume that Trump is also among the US leaders who like to hunt for war. It is just that if observed in several cases, including cases of tension with Iran, he seemed to appear softened before the facts; that Iran cannot be compared to the weak countries in the Middle East because, since the beginning of the initiation of an open war with Iran, it was the primary option always encouraged by its military advisers. Although in the end, Trump chose to cancel the attack at the last second to cause tension between Trump and his National Security Adviser, John Bolton, who then ended with his dismissal by Trump (Kompas, n.d.).

At this point, it appears that Trump is experiencing symptoms of repression in which the ego mechanism relies on the defense of the subconscious to maintain its existence from feelings of anxiety or depression that always overshadow when panic, conflict, and threatened (Az-Zaghul 2004, 285). in the situation of facing various challenges both outside and inside, finally, John Bolton, as the main stumbling block in deciding policies, must be discarded, even though both of them have a skeptical attitude toward multilateralism.

\section{CONCLUSION}

The tensions between the United States and Iran, as can be witnessed lately, have reached the rare point of several escalations in recent years, especially in the Middle East. Apart from the historical factors that began since Iran succeeded in carrying out a revolution by subverting the regime of Shah Mohamed Reza Pahlavi, another factor heightening the geopolitical dynamics of the region was the departure of the US under President Donald Trump from the nuclear agreement of the Joint Comprehensive Plan of Action (JCPOA), followed by tighter economic sanctions on Iran. the escalation, which is increasing from time to time, cannot be separated from the series of sanctions imposed on Iran by the United States. There is intense pressure from America on Iran to immediately stop its nuclear program considered to have disrupted geopolitical stability in the Middle East.

Viewed from the perspective of national interest, America does not want a stable country influencing the political map in the region. If it happens, it will clash with its national interest. However, despite 
the escalation of the firing points of rivalry between the two countries, even the shooting down of the Global Hawk RQ-A4, a US military surveillance drone by the Islamic Revolution Guards Corps (IRGC) south of the Persian Gulf at 19:44 GMT on Wednesday, June 19, 2019, or 00:14 Thursday local time, no serious signs were leading to open war, except only limited to curses and expletives of the American president, Donald Trump, who at first had given orders to wage war against Iran. However, shortly after, he withdrew his orders under the pretext of humanity.

America, under the quite sarcastic president in addressing the Iran problem, seems to choose a more rational option by not deploying the military to face Iran. If this option is taken by the stakeholders, the Middle East situation will face a big open war by involving various proxies in various countries, especially those under Iran's influence. Therefore, due to the huge risk, America chose another option by tightening sanctions on Iran to cripple it economically so that Iran experiences domestic turmoil. Furthermore, this option no longer requires an open war, which will be detrimental to both parties, especially for Donald
Trump, who will step forward again to run for president for his second term in 2020. Trump is considering calculations for investment in the upcoming 2020 elections. If the war with Iran is carried out in the last period of his leadership, his votes will be very threatened. Hence, he chose to ignore the input of his advisers who tended toward open war. Besides, another important factor is that the Iranian military cannot be underestimated. Global Firepower data show that Iran is one of the most influential countries in the region and ranks $14^{\text {th }}$ in the world's strongest military. Indeed, it is excluding nuclear power.

\section{REFERENCES}

Al-Daghsyi, Ahmad Muhammad. 2013. Al-Hutsiyyun Wa Mustaqbaluhum Al-'Askari Wa Al-Siyasi Wa Al-Tarbawi. I. Doha: Muntada Al-Alaqat AlArabiyah wa Al-Duwaliyah.

Az-Zaghul, Imad Abdurrahman. 2004. Psikologi Militer. Translated by Ahmad Rivai Usman. Jakarta: Khalifa.

Burdah, Ibnu. 2008. Timur Tengah: Aktor, Isu, Dan Dinamika Konflik. Yogyakarta: Tiara Wacana. 
-_- 2014. Islam Kontemporer: Revolusi Dan Demokrasi. Malang: Intrans Publishing.

Eickelman, Dale F., and James Piscatori. 1998. Ekspresi Politik. Translated by Rofik Suhud. I. Bandung: Penerbit Mizan.

Esposito, John L. 1996. Ancaman Islam Mitos Atau Realitas? Translated by Alwiyah Abdurrahman. III. Bandung: Penerbit Mizan.

_-_. 1997. Political Islam: Revolution, Radicalism, or Reform? London: Lynne Rienner Publishers.

Esposito, John L., Mohammed Arkoun, and Mohammed 'Abed Al-Jabiri. 2002. Dialektika Peradaban: Modernisme Politik Dan Budaya Di Akhir Abad Ke-20. Translated by Ahmad Syahidah. I. Yogyakarta: Penerbit Qalam.

Gerges, Fawaz A. 2002. Amerika Dan Islam Politik: Benturan Peradaban Atau Benturan Kepentingan? Translated by Kili Priggodigdo and Hamid Basyaib. I. Jakarta: AlVaBet.

Hastedt, Glenn P., ed. 2000. American Foreign Policy: Past, Present Future. IV. Englewood Cliffs, NJ: Prentice-Hall.
Huntington, Samuel P. 2012. Benturan Antar Peradaban Dan Masa Depan Politik Dunia. Translated by M. Sadat Ismail. XII. Jakarta: Penerbit Qalam.

Morgenthau, Hans J. 2010. Politik Antarbangsa. Translated by S. Maimoen. Jakarta: Yayasan Pustaka Obor Indonesia.

Rogan, Eugene. 2017. Dari Puncak Khilafah: Sejarah Arab-Islam Sejak Era Kejayaan Khilafah Utsmaniyah. Translated by Fahmy Yamani. I. Jakarta: PT. Serambi Ilmu Semesta.

Sahide, Ahmad. 2017. Gejolah Politik Timur Tengah: Dinamika, Konflik, Dan Harapan. Yogyakarta: the Phinisi Press.

Said, Edward W. 1986. Penjunkirbalikan Dunia Islam. Translated by Asep Hikmat. I. Bandung: Penerbit Pustaka.

-_-. 2016. Orientalisme: Menggugat Hegemoni Barat Dan Mendudukkan Timur Sebagai Subjek. Translated by Achmad Fawaid. II. Yogyakarta: Pustaka Pelajar.

Salim, Shalah. 2001. Hurub AlMantiqah Al-'Arabiyah: AlMauqif Al-Siyasi Al-Mishri. Kairo: Dar El-Shorouk.

Scott, Burchill. 2005. the National Interest in International 
Relations Theory. New York: Palgrave Macmillan.

Sihbudi, Reza. 2007. Menyandera

Timur Tengah. I. Bandung:

Penerbit Mizan.

Simon, Roger. 2004. Gagasan-

Gagasan Politik Gramsci.

IV. Yogyakarta: INSIST dan

Pustaka Pelajar.

Tamara, Nasir. 2017. Revolusi

Iran. II. Jakarta: Kepustakaan

Populer Gramedia.

Al-Khuri, Kabi. 2019. "Al-Malaf AlIhshai Al-Raqm 141 Bayanat Bi Al-Qadrat Al-'Askariyah Li Al-Juyusy Al-Arabiyah Muqaranatah Bi Turkiya Wa Iran Wa Israil." Arab Future, no. 485 (July): 165-76.

Mikail, Kiki. 2018. "Perjanjian Nuklir Iran dan Pengaruhnya terhadap Kepentingan USAIsrael di Timur Tengah." Jurnal ICMES 2 (1): 69-85. https:// doi.org/10.35748/jurnalicmes. v2i1.18.

Shaqiq, Munir. 2019. "Al-Hishar Al-Amriki 'Ala Iran, Ila Aina?" Arab Future, no. 486 (August): 119-21.

Wolf, Albert B. 2018. “After JCPOA: American Grand Strategy toward Iran." Comparative Strategy 37 (1): 22-34. https:// doi.org/10.1080/01495933.201 7.1419719 .

Yazdani, Enayatollah. 2019. "Confrontation Between America and the Islamic Republic of Iran-David Publishing Company." Sociologi Study 1 (9): 177-87.

Detik.com. 2019. “Trump Ungkap Alasan Batalkan Serangan Ke Iran Saat Menit Terakhir," 11 October 2019. https://m.detik.com/news/ internasional/d-4595824/ tru m p - ungkap - al as an batalkan-serangan-ke-iransaat-menit-akhir.

JakartaGreater. 2019. "Militer Iran Ungkap Lebih Detail Penembakan Drone AS," 12 October 2019. https:// jakartagreater.com/milliteriran-ungkap-lebih-detailpenembakan-drone-as/.

Kompas. n.d. "Akhir Seteru TrumpBolton." Print Version, Thursday 12 September 2019 edition.

- - . n.d. "Kilang Aramco Diserang Houthi." Print Version, Sunday 15 September 2019 edition.

n.d. "Perselisihan Baru IranAS." Print Version, Tuesday, 19 November 2019 edition. 
- _ - n.d. "Persenjataan Mahal, Tapi Kebobolan Juga." Print Version, Thursday 19 September 2019 edition.

-_- n.d. "Pilihan Sulit Rouhani." Print Version, Tuesday, 19 November 2019 edition.

Schemm, Paul, and Louisa Loveluck. 2019. “Iran Warns U.S. of 'All-out War' If Attacked." the Wasington Post, 20 September 2019. https://www.washingtonpost. com/world/middle_east/ iran-warns-us-of-all-outwar-if-attacked/2019/09/19/ 26c04864-da4c-11e9-a1a5162b8a9c9ca2_story.html. 